\title{
Efektivitas Kombinasi Pupuk Hayati Biofresh Plus Dengan Dosis Pupuk Anorganik NPK Dalam Meningkatkan Pertumbuhan Vegetatif Beberapa Varietas Kedelai (Glycine max L. Merrill) Di Lahan Ultisol
}

\section{The Effectiveness of Combination BiofertilizerBiofresh Plus With Doses of InorganicFertilizer NPK Different in Improving Vegetative Growth of Several Varieties Soybean (Glycine max L. Merrill) in The Land Ultisol}

\author{
Anwar $^{1}$, Andi Khaeruni ${ }^{2}$, Teguh Wijayanto ${ }^{2}$ \\ ${ }^{1}$ Mahasiswa Program Studi Agronomi Program Pascasarjan Universtas Halu Oleo \\ ${ }^{2}$ Dosen Pengajar Program Pascasarjan Universtas Halu Oleo Kendari \\ Diterima: 15 Juni 2019/Disetujui: 10 Juli 2019
}

\begin{abstract}
ABSTRAK
Penelitian ini bertujuan untuk mengkaji efektivitas kombinasi pupuk hayati Biofresh plus dengan dosis pupuk anorganik NPK yang berbeda dalam meningkatkan pertumbuhan vegetatif beberapa varietas kedelai di lahan Ultisol. Dilaksanakan di Laboratorium Proteksi Tanaman Unit Fitopatolgi Fakultas Pertanian Universitas Halu Oleo dan di Desa Lamomea Kecamatan Konda Kabupaten Konawe Selatan dari bulan Juli sampai bulan November 2016. Penelitian ini menggunakan Rancangan Petak Terbagi (RPT) dalam Rancangan Acak Kelompok (RAK). Petak utama adalah beberapa varietas kedelai terdiri dari 4 jenis yaitu varietas Argomulyo (V1), varietas Anjasmoro (V2), varietas Dering-1 (V3) dan varietas Dena-1 (V4). Anak petak adalah paket bioteknologi berbasis mikroba lokal yang terdiri 4 taraf yaitu penggunaan pupuk hayati Biofresh plus (B1), pupuk hayati Biofresh plus dengan pupuk anorganik 25\% dosis rekomendasi (B2), pupuk hayati Biofresh plus dengan pupuk anorganik 50\% dosis rekomendasi (B3) dan tehnik budidaya konvensional (pupuk anorganik 100\%) sebagai kontrol (B4). Sehingga terdapat 16 kombinasi perlakuan, setiap kombinasi perlakuan diulang sebanyak 3 kali sehingga terdapat 48 unit percobaan. Data hasil pengamatan di uji menggunakan metode sisik ragam dan dilanjutkan dengan Uji Jarak Berganda Duncan (UJBD). Variabel pengamatan meliputi tinggi tanaman dan jumlah daun. Hasil penelitian menujukkan bahwa pengaplikasian pupuk hayati Biofresh plus dengan dosis pupuk anorganik NPK yang berbeda pada beberapa varietas kedelai memberikan pengaruh interaksi terhadap jumlah daun pada 6 dan 8 MST. Pengaplikasian mandiri beberapa varietas atau kombinasi pupuk hayati Biofresh plus dengan dosis pupuk NPK yang berbeda memberikan pengaruh nyata pada tinggi tanaman, jumlah daun pada 2 dan 4 MST. Varietas Argomulyo yang diaplikasikan pupuk hayati Biofresh plus dengan dosis pupuk anorganik NPK 50\% rekomendasi memiliki respon pertumbuhan yang lebih baik dibandingkan dengan pemberian dosis pupuk anorganik NPK 100\% (kontrol).
\end{abstract}

Kata kunci: Pupuk hayati Biofresh, Varietas kedelai, pupuk anorganik NPK

\section{ABSTRACT}

This study aimed to assess the effectiveness of a combination of biological fertilizer Biofresh plus with doses of inorganic fertilizer NPK different in Improving Vegetative Gowth of some soybean varieties in land Ultisol. This research was conducted at the Laboratory of Plant Protection Unit Fitopatolgy the Faculty of Agriculture Halu Oleo university and in the Lamomea village of Sub-District Konda, South Konawe District from July to November 2016. This study used the Split Plot Design (SPD) in a Randomized Block Design (RBD). The main plot is some soybean varieties consists of 4 types of varieties Argomulyo (V1), varieties Anjasmoro (V2), varieties Dering-1(V3) and varieties of Dena-1 (V4). The subplots are packet-based biotechnology microbial locally comprises four levels ie use of biological fertilizers Biofresh plus (B1), a biological fertilizer Biofresh plus with inorganic fertilizers $25 \%$ dose recommendation (B2), a biological fertilizer Biofresh plus with inorganic fertilizers 50\% dose recommendation (B3) and conventional cultivation techniques (inorganic fertilizer 100\%) as a control (B4). So there are 16 combinations of treatments, each combination treatment was repeated 3 times so that there are 48 experimental units. The data were tested using a variety of scales and continued with Duncan Multiple Range Test (UJBD). The variables observed were plant height and number of leaves. The results showed that the application of biofertilizers Biofresh plus a dose of inorganic fertilizer NPK different in some soybean varieties provide interaction effect on the number of leaves at 6 and 8 weeks after planting, the number of productive branches. Application standalone several varieties or a combination of biological fertilizer Biofresh plus a dose of NPK fertilizer of different significant effect on plant height, number of leaves at 2 and 4 weeks after planting. Varieties Argomulyo applied biofertilizers Biofresh plus a dose of inorganic fertilizer NPK 50\% on growth response compared to the dose of inorganic fertilizer NPK 100\% (control),

Keywords: Biofertilizer Biofresh, soybean varieties, inorganic fertilizer NPK.

${ }^{*}$ Penulis untuk korespondensi. Email : andikhaeruni.uho@gmail.com 



\section{PENDAHULUAN}

Produksi kedelai nasional tahun 2015 mencapai 998.870 ton biji kering kedelai dengan luas panen 616.347 ha (produktivitas 1,56 ton ha ${ }^{-1}$ ), angka ini tercatat meningkat sekitar 43.870 ton atau setara 4,5\% dari produksi kedelai 2014 sebanyak 955.000 ton biji kering kedelai dengan luas panen 615.685 ha (produktivitas 1,55 ton ha $^{-1}$ ), begitu juga produksi kedelai Provinsi Sulawesi Tenggara pada tahun 2015 mengalami peningkatan sebanyak 7.108 ton biji kering kedelai $(124,90$ persen), dimana produksi kedelai tahun 2015 tersebut sebesar 12.799 ton, dengan luas panen 7.888 ha (produktivitas 1,62 ton ha ${ }^{1}$ ) dibandingkan tahun 2014, dimana produksi kedelai tahun 2014 sebesar 5.691 ton biji kering kedelai dengan luas panen 5.079 ha (produktivitas 1,12 ton ha 1. Peningkatan produksi kedelai terjadi karena kenaikan luas panen seluas 2.809 ha $(55,31 \%)$ dan produktivitas sebesar 0,51 ton $\mathrm{ha}^{-1}(44,81 \%)$ (BPS, 2015). Peningkatan produksi kedelai ini disebabkan karena perluasan areal pertanaman kedelai dan peningkatan produktivitas tanaman kedelai.

Peningkatan produksi ini tidak cukup tinggi untuk mengimbangi kebutuhan masyarakat yang mencapai 2.537.000 ton biji kering kedelai pertahun, sementara produksi tahun 2015 hanya mencapai 998.870 ton biji kering kedelai, sehingga untuk memenuhi kebutuhan masyarakat tersebut Indonesia melakukan impor kedelai sebesar 1.358 .130 ton biji kering kedelai (BPS, 2015).

Belum optimalnya penggunaan varietas kedelai unggul serta permasalahan organisme pengganggu tanaman menjadi faktor atau kendala terbesar dalam budidaya tanaman kedelai. Organisme pengganggu tanaman seperti penyakit mosaik virus yang disebabkan oleh Soybean mosaik virus (SMV) (Giesler, 2010) dan penyakit pustul bakteri yang disebabkan oleh Xanthomonas axonopodis pv. glycines (Xag) (Khaeruni et al., 2007), merupakan penyakit utama pada tanaman kedelai di Indonesia termasuk di Sulawesi Tenggara (Taufik et al., 2010; Khaeruni et al., 2015). Penyakit mosaik dapat mengakibatkan penurunan hasil panen kedelai 50-90\% (Rahmawati, 2012) dan penyakit pustul bakteri dapat menurunkan hasil panen tanaman kedelai pada tingkat serangan parah dan kondisi lingkungan mendukung berkisar antara 21-40 \% (Rahayu, 2005), umumnya menjadi kendala serius yang dihadapi oleh petani yang berimplikasi pada pencapaian produksi yang kurang maksimal pada tanaman kedelai.

Tidak dapat dipungkiri bahwa selama ini untuk meningkatkan daya dukung lahan, pengendalian hama dan penyakit tanaman dalam rangka peningkatan produktivitas lahan petani masih mengandalkan penggunaan pupuk kimia anorganik dan pestisisda sintetik. Penggunaan pupuk kimia anorganik dan pestisida sintetik yang berlebihan mengakibatkan tanah semakin tandus dan perkembangan hama dan penyakit tanaman sulit dikendalikan sehingga perlu dilakukan upaya yang solutif terhadap permasalahan tersebut.

Upaya alternatif yang dapat dilakukan untuk pemulihan kesuburan tanah atau meningkatkan daya dukung lahan-lahan marjinal adalah dengan pemanfaatan pupuk hayati (biofertilizer), penggunaan pupuk kimia secara berimbang dan varietas unggul. Penggunaan biofertilizer akan semakain efektif jika diaplikasikan dengan bahan organik dengan memanfaatkan sumberdaya alam lokal yang ada seperti pupuk kandang dan limbah hasil pertanian.

\section{METODE PENELITIAN \\ Tempat dan Waktu}

Penelitian ini dilaksanakan di Laboratorium Proteksi Tanaman Unit Fitopatolgi Fakultas Pertanian Universitas Halu Oleo dan di Desa Lamomea Kecamatan Konda Kabupaten Konawe Selatan dari bulan Juli sampai bulan November 2016.

\section{Bahan dan Alat}

Bahan yang digunakan adalah benih kedelai varietas Argomulyo, varietas Anjamoro, varietas Dering-1, varietas Dena-1, pupuk kandang kotoran sapi, gula pasir, EM4 (efective microorganism) serasah kedelai, pupuk hayati Biofresh, pupuk anorganik (Urea, SP36, dan KCL), kapur dolomit $\left(\mathrm{CaCO}_{3}\right)$, air, tissue, spritus, aquades, alkohol $70 \%$ dan media NA

Alat yang digunakan adalah plat label, pacul, terpal, parang, sekop, gembor, mistar, laminar air flow cabinet, incubator, lampu bunsen, gelas kimia, erlenmeyer, gelas ukur, jarum ose, timbangan analitik, cawan petri, botol schoot, shaker, hot plate, oven, autoclave, kamera dan alat tulis menulis.

\section{Rancangan Penelitian}

Rancangan penelitian digunakan adalah Rancangan Petak Terbagi (RPT) dalam Rancangan Acak Kelompok (RAK). Petak utama adalah jenis varietas yang terdiri dari 4 taraf yaitu varietas Argomulyo (V1), varietas Anjasmoro (V2), varietas Dering-1 (V3) dan varietas Dena-1 (V4). Anak petak adalah paket bioteknologi berbasis mikrob lokal yang terdiri 4 taraf yaitu penggunaan pupuk hayati Biofresh plus (B1), pupuk hayati Biofresh plus dengan pupuk anorganik 25\% dosis rekomendasi (B2), pupuk hayati Biofresh plus dengan pupuk anorganik 50\% dosis rekomendasi (B3) dan tehnik budidaya konvensional (pupuk anorganik 100\%) sebagai kontrol (B4). Sehingga terdapat 16 kombinasi perlakuan, setiap kombinasi perlakuan diulang sebanyak 3 kali sehingga terdapat 48 unit percobaan. Data hasil pengamatan di uji menggunakan metode 
sisik ragam dan dilanjutkan dengan Uji Jarak Berganda Duncan (UJBD).

\section{Prosedur Pembuatan Bokashi}

Pembuatan bokashi dilakukan dengan cara mencampurkan bahan organik (serasah kedelai) dengan pupuk kandang secara merata, kemudian disiram dengan larutan EM-4 yang telah dicampurkan air dan gula pasir terlebih dahulu dan ditutup rapat dengan terpal. Untuk menjaga kondisi suhu pada Bokashi, maka setiap hari dilakukan pembalikan Bokashi selama 7 hari. Bokashi yang matang dan siap digunakan memiliki ciri berwarna hitam, tidak berbau. Persiapan Lahan

Pengolahan tanah dilakukan sebanyak 2 kali agar tanahnya menjadi gembur, kemudian dibuat bedengan berukuran $4 \mathrm{~m}$ x $5 \mathrm{~m}$, sebanyak 48 bedengan dengan tinggi $30 \mathrm{~cm}$. Jarak antar bedengan dalam kelompok $30 \mathrm{~cm}$ sedangkan jarak antar kelompok $50 \mathrm{~cm}$.

\section{Pengapuran}

Pengapuran dilakukan 2 minggu sebelum tanam. Pengapuran dilakukan dengan cara menabur kapur Dolomit $\left(\mathrm{CaMg}\left(\mathrm{CO}_{2}\right)_{2}\right)$ diatas permukaan bedengan secara merata dengan dosis 1,5 ton $\mathrm{ha}^{-1}$.

\section{Aplikasi Bokashi}

Aplikasi Bokashi dilakukan 2 minggu sebelum tanam dengan cara menabur Bokashi secara merata di atas permukaan petakan sesuai dengan petak perlakuannya masing-masing (perlakuan bokashi serasah kedelai 100\%) dosis aplikasi Bokashi ini yaitu 10 ton $\mathrm{ha}^{-1}$, kemudian petakan diolah kembali sehingga Bokashi terbenam dalam tanah secara merata.

\section{Aplikasi Pupuk Hayati.}

Aplikasi pupuk hayati Biofresh dilakukan sebanyak dua kali. Aplikasi pertama bersamaan dengan waktu penanaman, dengan cara menjadikan pupuk hayati Biofresh ini sebagai penutup lubang tanam. Aplikasi kedua dilakukan pada umur tanaman 4 minggu setelah tanam dengan cara menaburkan didekat perakaran tanaman. Setiap kali aplikasi diberikan dengan dosis 10 gram per rumpun tanaman.

\section{Penanaman}

Sebelum dilakukan penanaman terlebih dahulu benih diberi perlakuan, untuk benih dengan perlakuan pupuk hayati Biofresh dilakukan Biopriming benih selama 1 jam dengan suspensi rizobakteri bahan aktif Biofresh yang dibuat dengan kerapatan $10^{10}-10^{11} \mathrm{cfu}$ $\mathrm{ml}^{-1}$ atau nilai Optical Density $=2$, sedangkan untuk benih kedelai tanpa perlakuan pupuk hayati Biofresh hanya direndam menggunakan aquades selama 1 jam, kemudian masing-masing di shaker dengan kecepatan $150 \mathrm{rpm}$. Setelah itu dilakukan penanaman dengan cara membuat lubang tanam sedalam $3 \mathrm{~cm}$, lalu memasukkan benih sebanyak 3 biji perlubang, dengan jarak tanam yang digunakan yaitu $30 \mathrm{~cm}$ x 25 $\mathrm{cm}$.

\section{Aplikasi Pupuk Anorganik}

Pupuk anorganik yang digunakan adalah pupuk Urea, SP36 dan KCL dengan dosis anjuran masingmasing yaitu urea $100 \mathrm{~kg} \mathrm{ha}^{-1}$, SP36 $125 \mathrm{~kg} \mathrm{ha}^{-1}$ dan $\mathrm{KCl} 85 \mathrm{~kg} \mathrm{ha}^{-1}$. Pemberian pupuk anorganik (Urea, SP36 dan KCL) diberikan pada tanaman kedelai berumur 2 minggu setelah tanam pada masing-masing petak yang diujikan, dengan cara tugal di sekitar tanaman.

\section{Pemeliharaan Tanaman}

Pemeliharaan tanaman meliputi penyulaman, penyiangan dan penyiraman. Penyulaman dilakukan pada saat 1 minggu setelah tanaman, yaitu dengan cara mengganti tanaman yang mati atau pertumbuhannya yang kurang baik. Penyiangan dilakukan dengan cara mencabut atau memotong gulma yang tumbuh disekitar pertanaman pada umur 4 minggu setelah tanam. Penyiraman dilakukan pada waktu pagi atau sore hari dan dilakukan setiap hari (jika tidak turur hujan).

\section{Panen}

Panen dilakukan dengan cara memotong pangkal batang kedelai yang sudah matang fisiologis. Ciri tanaman yang sudah siap dipanen yaitu sebagian besar daun (90-95\%) sudah menguning kecoklatan lalu gugur, batang mengering dan berwarna kuning agak coklat, polong mulai berubah warna dari hijau menjadi kuning kecoklatan dan retak-retak atau polong sudah kelihatan tua.

\section{Peubah Pertumbuhan Tanaman}

Pengamatan dilakukan pada 10 tanaman sampel yang diambil secara acak diagonal pada setiap petak percobaan. Variabel pengamatan yang diamati meliputi:

1. Tinggi tanaman $(\mathrm{cm})$, diamati dari pangkal batang sampai dengan titik tumbuh tanaman pada umur 2 , 4, 6 dan 8 minggu setelah tanaman.

2. Jumlah daun tanaman, diamati dengan cara menghitung jumlah daun trifoliat yang telah terbuka sempurna pada umur 2, 4, 6 dan 8 minggu setelah tanaman. 



\section{J. Berkala Penelitian Agronomi 7 (1) : 32 - 37 (2019)}

\section{HASIL DAN PEMBAHASAN}

Keberhasilan budidaya tanaman yang ramah lingkungan memerlukan teknologi budidaya yang meminimalisasi penggunaan bahan-bahan sintetik namun mengoptimalkan pemanfaatan sumberdaya alam hayati lokal, penggunaan bahan organik, pemanfaatan pupuk hayati, penggunaan varietas tanaman yang resisten terhadap serangan organisme pengganggu tanaman dan memiliki potensi produksi tinggi diharapkan mampu untuk mengatasi pengembangan tanaman kedelai di Indonesia, khussunya di Sulawesi Tenggara untuk memenuhi kebutuhan konsumsi nasional yang semakin tahun semakin meningkat

Hasil pengamatan terhadap tinggi tanaman kedelai pada pengamatan 8 MST menunjukkan bahwa perlakuan jenis varietas Dering-1 dan varietas Dena-1 dan kombinasi pupuk hayati Biofresh plus dengan dosis pupuk anorganik NPK yang berbeda (B1 dan B3) mampu meningkatkan tinggi tanaman (Tabel 1 dan 2) dibandingkan dengan perlakuan lainnya. Sedangkan pengamatan parameter jumlah daun tanaman kedelai pada pengamatan 8 MST daun terbanyak ditunjukkan pada perlakuan varietas Dering-1 yang diberi Biofresh plus dengan dosis NPK $25 \%$ dengan rata-rata 22,83 helai (Tabel 2). Hal tersebut mengindikasikan bahwa perbedaan jenis varietas dan penggunaan pupuk hayati Biofresh plus dengan dosis pupuk anorganik NPK yang berbeda dapat menyebabkan terjadinya pertumbuhan tanaman yang berbeda pula, karena hubungan antara jenis tanaman dengan mikroorganisme tanah dapat bersifat kompatibel jika senyawa dan asam organik yang dikeluarkan oleh tanaman cocok dengan kebutuhan mikroorganisme tersebut. Penelitian ini sejalan dengan dengan penelitian Marliah et al, (2012) yang menunjukkan bahwa varietas tanaman yang berbeda akan menunjukkan pertumbuhan dan hasil yang berbeda walaupun ditanam pada kondisi lingkungan yang sama.

Hasil penelitian Vessey (2003) menunjukkan bahwa pengaplikasian pupuk hayati yang mengandung mikroorganisme hidup, yang ketika diaplikasikan kepada benih, permukaan tanaman, atau tanah dapat memacu pertumbuhan tanaman. Khaeruni et al. (2010) juga melaporkan bahwa mikroba penyusun pupuk hayati Biofresh yang terdiri atas rizobakteri Bacilus subtilis ST21B, Bacilus cereus ST21B dan Serratia SS29a mampu memproduksi hormon tumbuh (IAA), melarutkan fosfat, dan menfiksasi nitrogen dari udara. Lebih lanjut Thakuria et al. (2004), bahwa kemampuan rizobakteri sebagai pemacu pertumbuhan tanaman ditunjukkan dengan kemampuan dalam menyediakan dan memobilisasi penyerapan berbagai unsur hara dalam tanah serta mensintesis dan mengubah kosentrasi berbagai fitohormon. Fadiluddin (2009) menambahkan keberadaan mikroba di dalam pupuk hayati dapat meningkatkan pertumbuhan tanaman melalui fiksasi $\mathrm{N}$, membuat hara lebih tersedia dalam pelarutan $\mathrm{P}$ atau meningkatkan akses tanaman untuk mendapatkan unsur hara yang memadai.

Tabel 1. Pengaruh mandiri kombinasi pupuk hayati Biofresh plus dengan dosis pupuk anorganik NPK yang berbeda terhadap tinggi tanaman pada umur 2, 4, 6 dan 8 MST

\begin{tabular}{ccccc}
\hline Biofresh+Dosis & \multicolumn{4}{c}{ Rerata Tinggi Tanaman $(\mathrm{cm})$ MST } \\
\cline { 2 - 5 } Anorganik(B) & 2 & 4 & 6 & 8 \\
\hline B1 & $10,85 \mathrm{~b}$ & $22,25 \mathrm{a}$ & $46,74 \mathrm{a}$ & $57,03 \mathrm{a}$ \\
B2 & $11,14 \mathrm{a}$ & $21,34 \mathrm{a}$ & $46,83 \mathrm{a}$ & $55,87 \mathrm{ab}$ \\
B3 & $11,04 \mathrm{a}$ & $22,72 \mathrm{a}$ & $50,23 \mathrm{a}$ & $60,83 \mathrm{a}$ \\
B4 & $9,70 \mathrm{~b}$ & $19,77 \mathrm{~b}$ & $43,78 \mathrm{~b}$ & $52,62 \mathrm{~b}$ \\
\hline & $2=0,4543$ & $2=1,484$ & $2=2,748$ & $2=3,651$ \\
UJBD 0,05 & $3=0,4772$ & $3=1,559$ & $3=2,887$ & $3=3,853$ \\
& $4=0,4918$ & $4=1,607$ & $4=2,975$ & $4=3,953$
\end{tabular}

Keterangan: Angka-angka yang diikuti oleh huruf yang sama pada kolom yang sama tidak berbeda nyata pada UJBD 0,05 . 
Tabel 2. Pengaruh interaksi beberapa varietas kedelai dan kombinasi pupuk hayati Biofresh plus dengan dosis pupuk anorganik NPK yang berbeda terhadap jumlah daun pada umur 8 MST

\begin{tabular}{ccccccc}
\hline Faktor & \multicolumn{4}{c}{ Faktor Biofresh+Dosis Anorganik(B) } & \multicolumn{2}{c}{ UJBD 0,05 } \\
\cline { 2 - 7 } Varietas (V) & $\mathrm{B} 1$ & $\mathrm{~B} 2$ & $\mathrm{~B} 3$ & $\mathrm{~B} 4$ & $\mathrm{~V}$ pada B & B pada V \\
\hline V1 & $16,90 \mathrm{c}$ & $15,60 \mathrm{~d}$ & $15,97 \mathrm{c}$ & $14,87 \mathrm{c}$ & $2=0,876$ & $2=0,949$ \\
& $\mathrm{p}$ & $\mathrm{q}$ & $\mathrm{pq}$ & $\mathrm{q}$ & $3=0,921$ & $3=0,998$ \\
$\mathrm{~V} 2$ & $20,07 \mathrm{~b}$ & $18,10 \mathrm{~b}$ & $17,80 \mathrm{~b}$ & $17,97 \mathrm{~b}$ & $4=0,945$ & $4=1,024$ \\
& $\mathrm{p}$ & $\mathrm{q}$ & $\mathrm{q}$ & $\mathrm{q}$ & & \\
V3 & $22,00 \mathrm{a}$ & $22,83 \mathrm{a}$ & $21,20 \mathrm{a}$ & $21,97 \mathrm{a}$ & & \\
& $\mathrm{pq}$ & $\mathrm{p}$ & $\mathrm{q}$ & $\mathrm{pq}$ & & \\
$\mathrm{V} 4$ & $17,17 \mathrm{c}$ & $16,83 \mathrm{c}$ & $15,50 \mathrm{c}$ & $14,70 \mathrm{c}$ & & \\
& $\mathrm{p}$ & $\mathrm{p}$ & $\mathrm{q}$ & $\mathrm{q}$ & & \\
\hline
\end{tabular}

Keterangan: Angka-angka yang diikuti oleh huruf yang sama pada baris (pq) dan kolom (abc) yang sama tidak berbeda nyata pada UJBD 0,05. V1=Varietas Argomulyo, V2=Varietas Anjasmoro, V3=Varietas Dering-1, V4=Varietas Dena-1. B1=Pupuk Hayati Biofresh Plus, B2=Pupuk Hayati Biofresh Plus dengan Dosis Pupuk Anorganik 25\%, B3=Pupuk Hayati Biofresh Plus dengan Dosis Pupuk Anorganik 50\%, B4=Pupuk Anorganik 100\%

\section{KESIMPULAN}

1. Pengaplikasian pupuk hayati Biofresh plus dengan dosis pupuk anorganik NPK yang berbeda pada beberapa varietas kedelai memberikan pengaruh interaksi terhadap jumlah daun pada 6 dan 8 MST

2. Pengaplikasian mandiri beberapa varietas atau kombinasi pupuk hayati Biofresh plus dengan dosis pupuk NPK yang berbeda membrikan pengaruh nyata pada tinggi tanaman dan jumlah daun pada 2 dan 4 MST

3. Varietas Argomulyo yang diaplikasikan pupuk hayati Biofresh plus dengan dosis pupuk anorganik NPK 50\% rekomendasi memiliki respon pertumbuhan Vegetatif yang lebih baik dibanding varietas lainnya dan dibandingkan dengan pemberian dosis pupuk anorganik NPK $100 \%$ (kontrol).

\section{DAFTAR PUSTAKA}

Adam, 2013. Soybean [Glycine max (L.) Merrill] Seed Yield Response to High Temperature Stress During Reproductive Growth Stages. Crop Science, Volume 7(10): 1472-1479.

Badan Pusat Statistik Nasional. 201. Sulawesi Tenggara Dalam Angka. Badan Pusat Statistik Provinsi Sulawesi Tenggara, Kendari.

Badan Pusat Statistik Nasional. 2015. Sulawesi Tenggara Dalam Angka. Badan

Pusat Statistik Provinsi Sulawesi Tenggara, Kendari.

Badan Pusat Statistik, 2015. Statistik Indonesia
Fadiluddin,M. 2009. Efektivitas Formula Pupuk Hayati dalam Memacu Serapan Hara, Produksi dan Kualitas Hasil Jagung dan Padi Gogo di Lapang. Tesis. Mayor Biologi Tumbuhan, Sekolah Pasca Sarjana, Institut Pertanian Bogor. Bogor. $69 \mathrm{hlm}$.

Giesler, L.G. 2010. Soybean Mosaic Virus. Extension Services. University of Nebrask.

Hanafiah, K.A. 2005. Dasar-Dasar Ilmu Tanah. Jakarta : PT. Raja Grafindo Persada.

Khaeruni,A., A. Suwanto, B. Tjahjono, dan S.M. Sinaga. 2007. Deteksi Cepat Penyakit Pustul Bakteri pada Kedelai Menggunakan Teknik PCR dengan Primer Spesifik. Hayati Journal of Biosciences. Volume 14 (2): 76-80.

Khaeruni, A., T. Wijayanto, G.A.K. Sutariati, Asniah and Sulqifly. 2015. Improvement of resistense agens pathogens, grow and yield of soybean on marginal land using indigenous rhizobacteria formulation recen advance in mathemathical and computational methods. P. 194-200. Proceeding of WSEAS conference. Kuala Lumpur, Malaysia April 23-25 2015.

Khaeruni, A., Sutariati G.A.K., S. Wahyuni.2010. Eksplorasi dan karakterisasi Bakteri Rizosfer untuk Pengembangan Biofretilizer dan Bioprotecting pada Tanah Marjinal Podsolik Merah Kuning (Lanjutan). Laporan Penelitian Insentif Dasar Ristek. Lembaga Penelitian Universitas Halu Oleo.

Marliah, N., Nurhayati dan Tarmizi. 2012. Effects of Mulch and Liquid Organic Fertilizer Super 
Bionik On Growth and Yield of Onion (Allium ascalonicum L.). Jurnal Floratek. Volume 7: $164-172$.

Rahayu, M. 2005. Tanggapan Varietas Kedelai terhadap Penyakit Pustul Xanthomonasaxonopodis dan Potensi Ekstrak Nabati untuk Pengendaliannya.Balai PenelitianTanaman Kacang-kacangan dan Umbi-

umbian.mhttp://balitkabi.litbang.deptan.go.i $d /$.[16juni 2008].

Rahmawati, 2012. Cepat dan Tepat Berantas Hama dan Penyakit Tanaman. Pustaka Baru Pres: Yogyakarta.

Taufik, M., A. Rahman, A. Wahab dan S.H. Hidayat. 2010. Mekanisme Ketahanan Terinduksi oleh Plant Growth Promotting Rhizobacteria (PGPR) pada Tanaman Cabai Terinveksi Cucumber Mosaic Virus (CMV). Jurnal Hortilkultura. 20(3): 274-283.

Thakuria, D., N.C. Talukdar, C. Goswami, S. Hazarika, R.C. Boro, and M.R. Khan. 2004. Characterization and screening of Bacteria from rhizospher of rice grown in acidic soils of assam. Curren Sci. 86: 978985

Vessey, J.K. 2003. Plant growth promoting rhizobacteria as biofertilizer. Plant Soil. Vol 255:571-58 